\title{
RADIOCARBON DATING OF BIOCHEMICALLY CHARACTERIZED HAIR
}

\author{
R. E. TAYLOR, ${ }^{1,2}$ P. E. HARE, ${ }^{3}$ CHRISTINE A. PRIOR, ${ }^{1}$ DONNA L. KIRNER, ${ }^{1}$ \\ LIJUN WAN ${ }^{1}$ and RICHARD R. BURKY ${ }^{1}$
}

\begin{abstract}
A series of ${ }^{14} \mathrm{C}$ determinations have been obtained on hair samples principally from Holocene contexts that have been variously pretreated to examine different means of removing potential contamination. SEM photomicrographs have documented hair surfaces before and after different pretreatments. Amino-acid composition, $\mathrm{C} / \mathrm{N}$ ratios and $\delta^{13} \mathrm{C}$ values have been obtained to biochemically characterize these samples and provide baseline data for future comparisons with less well-preserved samples. Our data support the view that appropriately pretreated hair samples can provide accurate ${ }^{14} \mathrm{C}$ age
determinations.
\end{abstract}

\section{INTRODUCTION}

In the original hierarchy of Libby's five recommended ${ }^{14} \mathrm{C}$ sample types, "well-preserved antler and similar hairy structures" were listed fourth ahead of only "well-preserved shell" (Libby 1952: 43). Bone was not included on his list, even though collagen is the characteristic protein in both antler and bone (Jope 1980). Anticipating future problems, Libby expressed the view that bone would be a very marginal sample type because the "carbon content of bone is extremely low, being largely in inorganic form in a very porous structure" (Libby 1955: 45). By contrast, hair contains relatively large amounts of organic carbon and is protected with a "hard" surface covering.

The general context for this study is an interest in developing criteria to evaluate direct ${ }^{14} \mathrm{C}$ age inferences on materials with unquestioned human attribution in cases where human bone has not been recovered or where available human bone samples contain only small or trace amounts of recoverable collagen. Previous studies have indicated that these types of bone samples exhibit, in many cases, anomalous ${ }^{14} \mathrm{C}$ dating results. If ${ }^{14} \mathrm{C}$ determinations on an appropriate fraction of hair could be shown to provide generally accurate age estimates, and if objective criteria are available by which hair fragments can be determined unambiguously to derive from Homo sapiens, the ability to provide well-supported age assignments for what have previously been called "critical" samples would be materially enhanced. "Critical" here refers to situations in which ${ }^{14} \mathrm{C}$ data is central in supporting or refuting some inference of major archaeological significance (Taylor 1987). An example of such a critical sample would be human hair from a site in the western hemisphere purported to be older than late terminal Pleistocene, i.e., pre-Clovis (Taylor 1992; Haynes 1992).

\section{RADIOCARBON DATING OF HAIR}

The first ${ }^{14} \mathrm{C}$ determinations on keratin-containing samples were obtained in 1953 by the Chicago laboratory (Libby 1955). The samples were human hair recovered at the Egyptian predynastic site of Nagada. The site had been excavated in 1896 by William M. Flinders Petrie (1853-1942), a major figure in the development of modern scientific archaeology. The hair samples were from graves containing ceramics whose relative chronology, based on design and stylistic characteristics, had been used by Petrie to develop his sequence dating scheme, the first formal seriation-type relative chronological method used in Near Eastern archaeology.

\footnotetext{
${ }^{1}$ Radiocarbon Laboratory, Department of Anthropology, University of California, Riverside, California 92521-0418 USA

${ }^{2}$ Also, Institute of Geophysics and Planetary Physics, University of California, Riverside

${ }^{3}$ Geophysical Laboratory, Carnegie Institution of Washington, 5251 Broad Branch Road NW, Washington, DC 20015-1305

USA. Work was carried out during tenure as Regents' Lecturer, University of California, Riverside.
} 
Because of the gram amounts of hair required for solid carbon decay counting, the practical limitations of using hair were exemplified from the very beginning, in that human hair samples from 2-4 grave lots at Nagada had to be combined to obtain a sufficient sample size for all three Chicago ${ }^{14} \mathrm{C}$ determinations. The development of gas-proportional counting using smaller detectors helped mitigate this problem. A sample of mammoth (Mammuthus primigenius) hair was ${ }^{14} \mathrm{C}$-dated as part of a biochemical study of the long-term stability of alpha-keratin structures (Gillespie 1970). A value of $32,700_{-860}^{+1040}$ BP (St-1632) was obtained on hair from the Dome Creek (Alaska) Mammoth by the Radiocarbon Laboratory of the Geological Survey of Sweden. To remove potential contamination, the hair was treated with weak $\mathrm{HCl}$ and washed with $\mathrm{H}_{2} \mathrm{O}$ (S. Claesson, personal communication 1993).

The advent of accelerator mass spectrometry (AMS) technology opened up for renewed examination the ${ }^{14} \mathrm{C}$ dating of hair. The obvious advantage is the drastic reduction in sample-size requirements, and thus, the ability to measure milligram quantities of chemical fractions that may be less susceptible to contamination. The Oxford AMS laboratory previously has analyzed human and animal (e.g., wool) hair from archaeological contexts (Hedges et al. 1987, 1988, 1993). At that laboratory, hair is pretreated by washing first with petroleum ether, followed by an acid/base/acid (ABA) treatment and a total hydrolysis, injection on an ion-exchange column and elution of a total amino acid fraction (R. E. M. Hedges, personal communication 1993). The NSF-Arizona Accelerator Facility pretreats hair using an ABA application (L. Toolin, personal communication 1993).

\section{ChaRACTERIZATION OF KERATIN}

Biochemically, hair is characterized by the protein keratin. The term keratin (Greek for "horn") was originally used to denote a group of complex, insoluble tissue proteins that formed the "horny layer" of the mammalian epidermis and its extensions (e.g., hair, feathers, nails and claws). More recently, the term has been narrowed to members of a family of intermediate filament proteins spanning the molecular weight range of 40 to 70 kiloDaltons (Goldman and Steinert 1990; Yu et al. 1993). The most extensive studies of hair structure have focused on sheep and human hair (Butcher and Sognnaes 1962; Marshall 1983; Sperling 1991).

Although hair is a "soft" keratin-containing tissue (in contrast to "hard" keratins such as horns and hoofs), it is resistant to attack by proteolytic enzymes such as pepsin or trypsin. This results in its durability in the natural environment (Fraser, MacRae and Rogers 1972) rendering it insoluble in water, dilute acids or alkali, and various organic solvents at ambient temperatures (Barrnett and Sognnaes 1962). The durable character of keratin arises, in large part, from its increased utilization of disulfide bonding, with the consequence that cystine is enriched in keratins when compared to collagen.

Although this unreactive characteristic made it difficult to study the chemical properties of keratin, this durability should make keratin more resistant to diagenetic processes that complicate the ${ }^{14} \mathrm{C}$ dating of bone (Stafford et al. 1990, 1991; Stafford 1994; Taylor 1994).

In comparison with bone: 1) keratin is present initially as a larger fraction of the total hair (>90\%; ca. $20 \%$ of fresh, dry, bone is composed of collagen); 2 ) the carbon content of keratin is higher ( $42 \%$ carbon content for keratin; $36 \%$ carbon content for collagen); and 3) the structural and biochemical characteristics of hair-a hard surface cuticle or layer of scales covering the hair shaft and the strong disulfide-bonded molecular structure-should significantly slow diagenetic degradation processes. 


\section{METHODS AND RESULTS}

We obtained a suite of ${ }^{14} \mathrm{C}$ values and other data on hair and bone samples from human skeletons recovered from cave and rock shelters near Reno, western Nevada. We also examined a sample of hair from Pendejo Cave, near Orogrande, New Mexico (Fig. 1). Pretreatment and graphitization were performed at the UCR laboratory (Kirner, Taylor, and Southon 1995) and ${ }^{14} \mathrm{C}$ measurements were performed at the Center for Accelerator Mass Spectrometry (CAMS), University of California Lawrence Livermore National Laboratory (LLNL) (Southon et al. 1990, 1992). ${ }^{14} \mathrm{C}$ values are expressed as conventional ${ }^{14} \mathrm{C}$ ages, i.e., normalized to $-25 \% o \delta^{13} \mathrm{C}$.

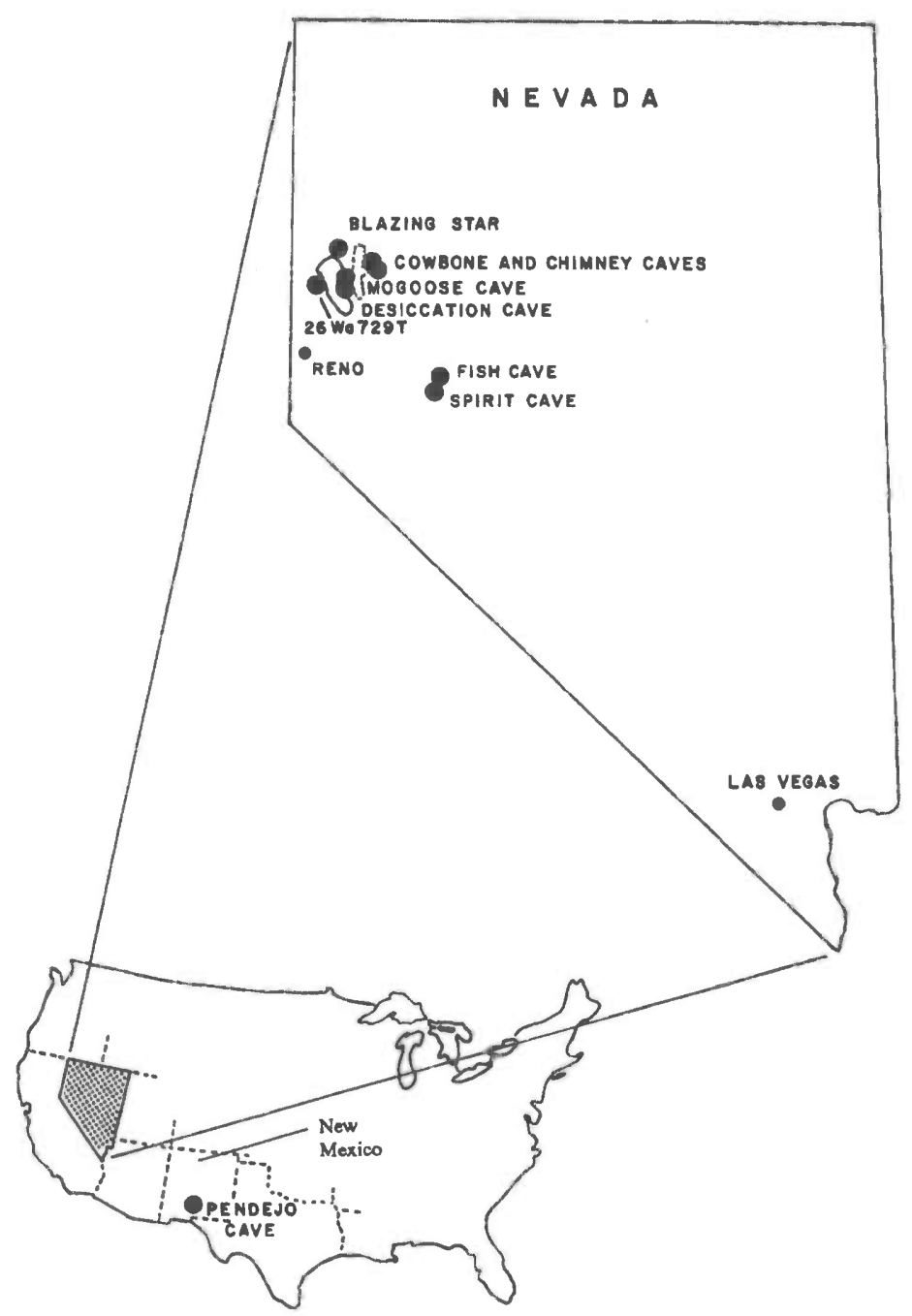

Fig. 1. Cave and rock shelter sites from which hair and bone samples were obtained. See Table 1 for full site and skeletal designations. 
Most of the Nevada human skeletons were recovered by S. M. Wheeler and G. N. Wheeler between 1930 and 1945 (Wheeler 1943; Wheeler and Wheeler 1969) and are curated at the Nevada State Museum, Carson City. The hair samples from Pendejo Cave were recovered as part of the excavations undertaken by the Andover Foundation for Archaeological Research, Andover, Massachusetts (MacNeish et al. 1993). Selected hair samples from Pendejo Cave were identified by staff of the Hair and Fibers Unit, Forensic Sciences Division, Federal Bureau of Investigation Laboratory, Washington, DC as bear (C. J. Hopkins, personal communication). However, some samples have been identified by another investigator as human (D. Chrisman, personal communication).

When viewed under a light microscope, each of the Nevada and Pendejo Cave hair samples exhibited surface contamination, which was examined further using a scanning electron microscope (JEOL model JSM-35C). Figure 2A is a scanning electron microscope (SEM) photograph illustrating the surface-adhering material on one of the hairs from the Blazing Star Cave, Nevada human skeleton. For the human hair samples, we examined the effect of various pretreatments on the ${ }^{14} \mathrm{C}$ values obtained. Four levels of pretreatment were applied to hair from four of the Nevada burials: 1 ) no pretreatment with only extraneous dirt and debris physically removed; 2) sonication in distilled water and air drying on glass filter paper; 3) sonication in a detergent followed by sonication in water and air drying on glass filter paper; and 4) sonication in distilled water, followed by acid hydrolysis and the isolation of a total amino acid (TAA) fraction using ion-exchange chromatography. We also obtained a TAA fraction from each of the associated bone samples.

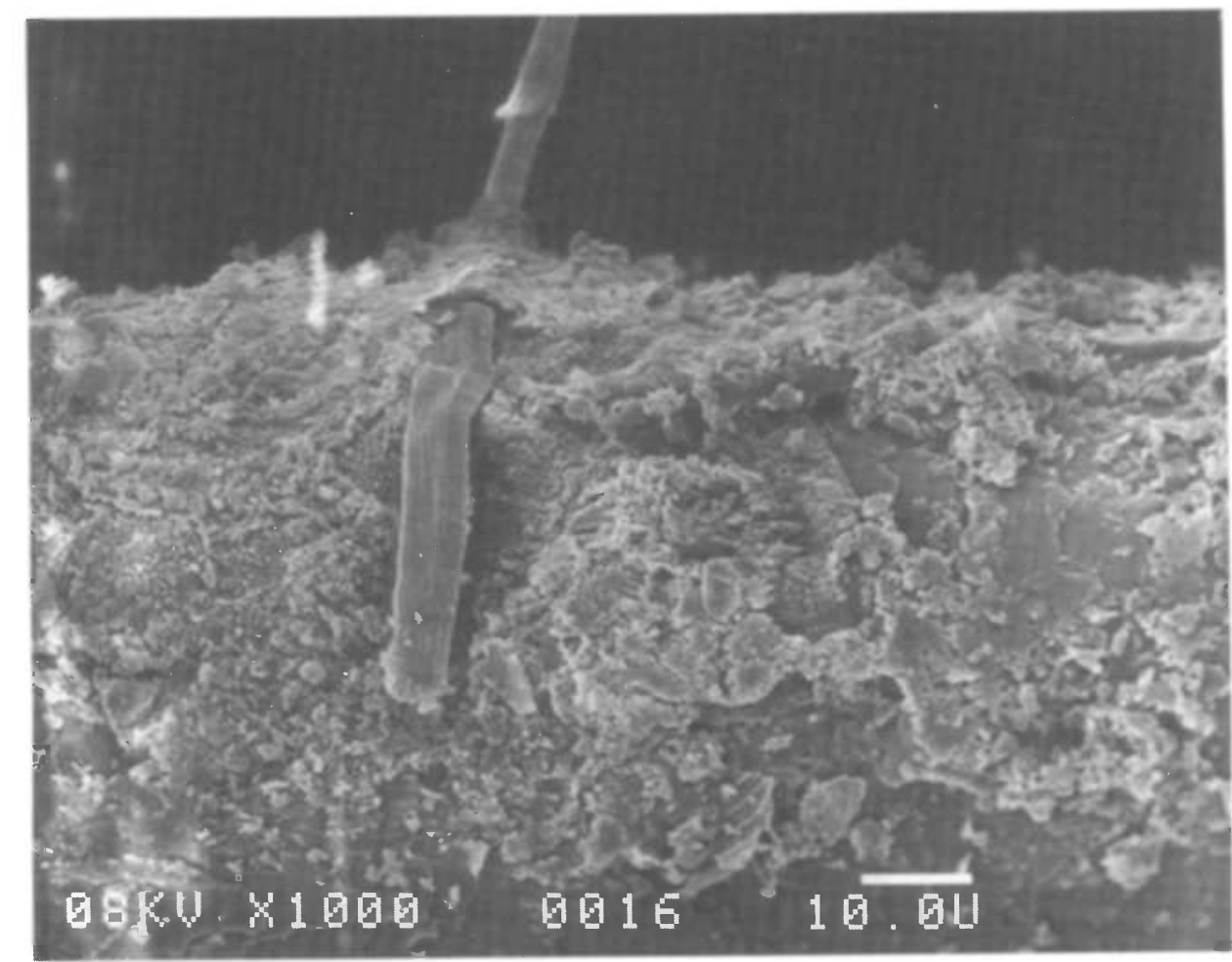

Fig. 2. SEM photomicrographs of Nevada hair (1000 times magnification): Blazing Star Cave hair A. before pretreatment, B. after sonication in water, C. Pyramid Lake Cave-729t hair after treatment with Brulin 815-GD detergent. White bar $=10 \mu$. 

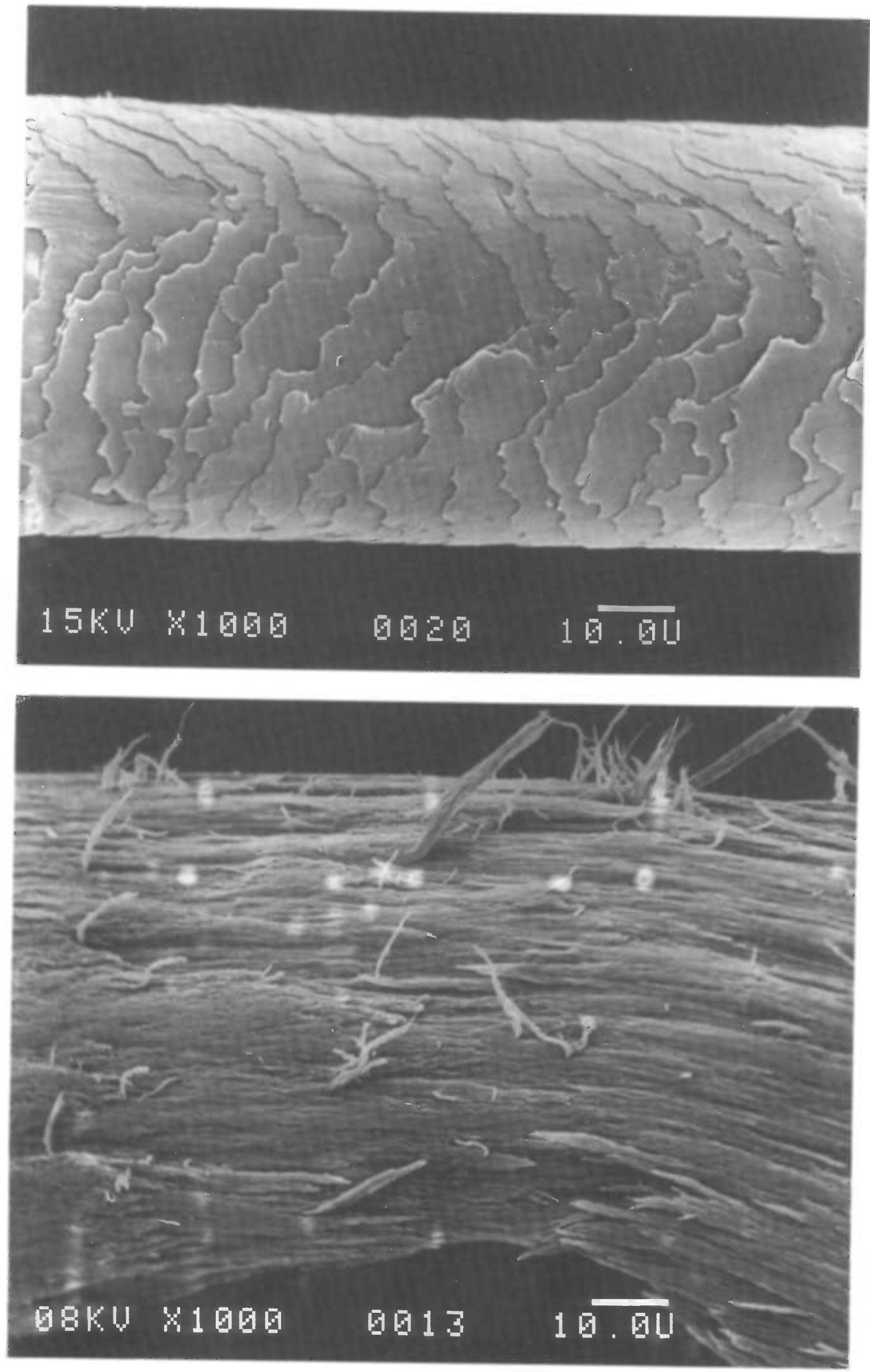

Fig. 2 B, C. See Fig. 2 A. 
We examined the effectiveness of using a detergent to remove surface-adhering foreign material rather than an organic solvent to avoid the remote possibility that trace amounts of the solvent would not be removed from very small samples. The detergent used was Brulin 815-GD (Brulin and Company, Inc., Indianapolis, Indiana, USA) which, we had been informed by the manufacturer, contained no carbon. We found the carbon content to be $9.48 \%$ which exhibited a $20.6 \pm 1.6 \mathrm{pMC}$ apparent ${ }^{14} \mathrm{C}$ activity (UCR-3320/CAMS-11350, $\delta^{13} \mathrm{C}=-28.6 \%$ ).

TABLE 1. Radiocarbon Age Determinations on Human Skeletons from Cave and Rock Shelter Sites in Nevada

\begin{tabular}{|c|c|c|c|c|c|}
\hline $\begin{array}{l}\text { Site/sample } \\
\text { designation }\end{array}$ & $\begin{array}{l}\text { Sample } \\
\text { type }\end{array}$ & Fraction & Sample no. & $\begin{array}{c}{ }^{14} \mathrm{C} \text { age } \\
\text { (yr BP) }\end{array}$ & $\begin{array}{l}\delta^{13} \mathrm{C} \\
(\% o)\end{array}$ \\
\hline $\begin{array}{l}\text { Desiccation Cave } \\
\text { (26-Wa-291; } \\
\text { AHUR-778) }\end{array}$ & Bone & $\begin{array}{l}\text { No pretreatment } \\
\text { Water only } \\
\text { Detergent treated } \\
\text { TAA } \\
\text { TAA }\end{array}$ & $\begin{array}{l}\text { UCR-3267A/CAMS-11349 } \\
\text { UCR-3267B/CAMS-11359 } \\
\text { UCR-3267C/CAMS-12368 } \\
\text { UCR-3267D/CAMS-12361 } \\
\text { UCR-3266/CAMS-12359 }\end{array}$ & $\begin{array}{l}1380 \pm 60 \\
1400 \pm 60 \\
1560 \pm 60 \\
1540 \pm 60 \\
1620 \pm 90\end{array}$ & $\begin{array}{l}-19.2 \\
-18.5 \\
-18.1 \\
-17.8 \\
-16.3\end{array}$ \\
\hline $\begin{array}{l}\text { Pyramid Lake } \\
\text { Cave-729t; } \\
\text { (26-Wa-729t; } \\
\text { AHUR-809) }\end{array}$ & Hair* & $\begin{array}{l}\text { No pretreatment } \\
\text { Water only } \\
\text { Detergent treated } \\
\text { TAA }\end{array}$ & $\begin{array}{l}\text { UCR-3269A/CAMS-11351 } \\
\text { UCR-3269B/CAMS-11360 } \\
\text { UCR-3269C/CAMS-11356 } \\
\text { UCR-3269D/CAMS-12362 }\end{array}$ & $\begin{array}{l}1570 \pm 60 \\
1620 \pm 60 \\
1590 \pm 60 \\
1690 \pm 50\end{array}$ & $\begin{array}{l}-19.1 \\
-19 \dagger \\
-19.2 \\
-18.5\end{array}$ \\
\hline $\begin{array}{l}\text { Mogoose Cave } \\
\text { (Pyramid Lake, } \\
\text { 26-Wa-275; } \\
\text { AHUR-840 }\end{array}$ & $\begin{array}{l}\text { Hair } \\
\text { Bone }\end{array}$ & $\begin{array}{l}\text { Water only } \\
\text { TAA } \\
\text { TAA } \\
\text { TAA }\end{array}$ & $\begin{array}{l}\text { UCR-3271B/CAMS-12370 } \\
\text { UCR-3271D/CAMS-12369 } \\
\text { UCR-3270/CAMS-12363 } \\
\text { UCR-3270/CAMS-14519 }\end{array}$ & $\begin{array}{l}2120 \pm 60 \\
2170 \pm 60 \\
3630 \pm 60 \\
4790 \pm 60\end{array}$ & $\begin{array}{l}-17.6 \\
-16.6 \\
-16.2 \\
-16 \dagger\end{array}$ \\
\hline $\begin{array}{l}\text { Fish Cave } \\
\text { (26-Ch-1e; } \\
\text { AHUR-2063) }\end{array}$ & Bone & $\begin{array}{l}\text { No pretreatment } \\
\text { Water only } \\
\text { Detergent treated } \\
\text { TAA } \\
\text { TAA }\end{array}$ & $\begin{array}{l}\text { UCR-3259A/CAMS-10910 } \\
\text { UCR-3259B/CAMS-11357 } \\
\text { UCR-3259C/CAMS-10911 } \\
\text { UCR-3259D/CAMS-11348 } \\
\text { UCR-3258/CAMS-14231 }\end{array}$ & $\begin{array}{l}2660 \pm 60 \\
2450 \pm 60 \ddagger \\
2530 \pm 60 \\
2390 \pm 60 \\
2350 \pm 100\end{array}$ & $\begin{array}{l}-16.8 \\
-17.3 \\
-17 \dagger \\
-16.9 \\
-16.6\end{array}$ \\
\hline $\begin{array}{l}\text { Cowbone Cave } \\
\text { (26-Pe-3c; } \\
\text { AHUR-734) }\end{array}$ & $\begin{array}{l}\text { Hair } \\
\text { Bone }\end{array}$ & $\begin{array}{l}\text { Water only } \\
\text { TAA } \\
\text { TAA }\end{array}$ & $\begin{array}{l}\text { UCR-3263B/CAMS-12360 } \\
\text { UCR-3263D/CAMS-12355 } \\
\text { UCR-3262/CAMS-14225 }\end{array}$ & $\begin{array}{l}2750 \pm 60 \\
2660 \pm 50 \\
2830 \pm 60 \S\end{array}$ & $\begin{array}{l}-17.2 \\
-16.7 \\
-15.0\end{array}$ \\
\hline $\begin{array}{l}\text { Chimney Cave } \\
(26-P e-3 b ; \\
\text { AHUR-919) }\end{array}$ & $\begin{array}{l}\text { Hair } \\
\text { Bone }\end{array}$ & $\begin{array}{l}\text { Water only } \\
\text { TAA } \\
\text { TAA }\end{array}$ & $\begin{array}{l}\text { UCR-3265B/CAMS-12358 } \\
\text { UCR-3265D/CAMS-12357 } \\
\text { UCR-3264/CAMS-12356 }\end{array}$ & $\begin{array}{l}3040 \pm 60 \\
3170 \pm 60 \\
3270 \pm 100\end{array}$ & $\begin{array}{l}-17.0 \\
-16.3 \\
-14.2\end{array}$ \\
\hline $\begin{array}{l}\text { Blazing Star Cave } \\
\text { (Pyramid Lake, } \\
\text { 26-Wa-525; } \\
\text { AHUR-866) }\end{array}$ & Bone & $\begin{array}{l}\text { no pretreatment } \\
\text { Water only } \\
\text { Detergent treated } \\
\text { TAA } \\
\text { TAA }\end{array}$ & $\begin{array}{l}\text { UCR-3273A/CAMS-11353 } \\
\text { UCR-3273B/CAMS-11362 } \\
\text { UCR-3273CCAMS-11364 } \\
\text { UCR-3273D/CAMS-11347 } \\
\text { UCR-3272/CAMS-12364 }\end{array}$ & $\begin{array}{l}4160 \pm 90 \\
4170 \pm 70 \\
4100 \pm 50 \\
4120 \pm 60 \\
4310 \pm 70\end{array}$ & $\begin{array}{l}-16.6 \\
-16.7 \\
-16 \dagger \\
-16.1 \\
-14.0\end{array}$ \\
\hline $\begin{array}{l}\text { Spirit Cave } \\
\text { (26-Ch-1f; } \\
\text { AHUR-2064) }\end{array}$ & $\begin{array}{l}\text { Hair } \\
\text { Bone }\end{array}$ & $\begin{array}{l}\text { Water only } \\
\text { TAA } \\
\text { TAA }\end{array}$ & $\begin{array}{l}\text { UCR-3261B/CAMS-12354 } \\
\text { UCR-3261D/CAMS-12353 } \\
\text { UCR-3260/CAMS-12352 }\end{array}$ & $\begin{array}{l}9360 \pm 60 \# \\
9350 \pm 70 \\
9430 \pm a 60\end{array}$ & $\begin{array}{l}-18.6 \\
-18.0 \\
-15.7 \\
\end{array}$ \\
\hline
\end{tabular}

*Plant fragments recovered from the hair (UCR-3268/CAMS-14226) yielded an age of $250 \pm 60 \mathrm{BP}$. †Estimated $\delta^{13} \mathrm{C}$ value

¥Another "water only" fraction (UCR-3259B/CAMS-10912) yielded an age of $3060 \pm 190 \mathrm{BP}$. This value is considered suspect because of the low beam current of the target.

$\S$ Another amino acid fraction (UCR-3262/CAMS-12996) yielded an age of $2480 \pm 60 \mathrm{BP}$. This value is considered suspect because of the low beam current of the target.

\#Duplicate sample (UCR-3261B/CAMS-1422)] yielded an age of $9450 \pm 60 \mathrm{BP}$. 
A series of SEM images were obtained to document the hair at each step in the cleaning process. Sonication in distilled $\mathrm{H}_{2} \mathrm{O}$ appears to be an effective method for removing adhering debris from the hair surfaces. Figure 2B shows the same hair in Figure 2A, following sonication in water. We also found that detergent pretreatment process is too aggressive for fossil hair samples, stripping off hair scales and exposing the interior of the hair fabric (Fig. 2C).

For the Nevada samples, Table 1 presents ${ }^{14} \mathrm{C}$ values for hair with up to four different pretreatment regimes compared (except in the case of Pyramid Lake-729t), with ${ }^{14} \mathrm{C}$ determinations on TAA fractions of bone from the same skeleton. For Desiccation Cave and Fish Cave materials, untreated hair samples were $c a .250 \mathrm{yr}$ older or younger than the TAA hair fractions. The untreated Desiccation Cave sample is younger, whereas the untreated Fish Cave hair is older. The Pyramid Lake-729t and Blazing Star Cave samples showed no statistically significant differences in the ${ }^{14} \mathrm{C}$ ages.

Although the ${ }^{14} \mathrm{C}$ values on the two fractions of the hair sample from Mogoose Cave show excellent agreement, there appears to be a major anomaly in the bone ${ }^{14} \mathrm{C}$ ages. Not only is there a significant divergence in the ages of the hair and bone samples but there is also a divergence in the ${ }^{14} \mathrm{C}$ ages exhibited by two bones purportedly from the same skeleton. Possible explanations are: 1) the cave was used for multiple internments; 2 ) skeletal parts may have been scattered by predators or packrats; 3 ) because the material was collected in the mid-1930s, there is also a possibility of curatorial error. The data in Table 1 suggest a ca. 100 -yr average offset between the ${ }^{14} \mathrm{C}$ ages of the hair and bone samples, the hair ${ }^{14} \mathrm{C}$ values tending to be somewhat younger than the bone values. However, in three cases, there is no statistical difference between the bone and hair values. The apparent small ${ }^{14} \mathrm{C}$ age offset between bone and hair may reflect differences in turnover rates these tissues (B. Marino, personal communication 1994).

Table 2 lists the ${ }^{14} \mathrm{C}$ ages obtained on hair from Pendejo Cave. $\mathrm{A}{ }^{14} \mathrm{C}$ age on wood from Zone $\mathrm{C}$ previously obtained by conventional decay counting is $c a .600$ yr older than the two hair ${ }^{14} \mathrm{C}$ valuesone obtained on water-treated hair and the other on a TAA fraction. The difference in age between the wood and hair ${ }^{14} \mathrm{C}$ values is not considered significant in light of the stratigraphical context of these samples.

TABLE 2. Radiocarbon Determinations on Hair and Associated Wood Samples from Zone $\mathrm{C} 2$ at Pendejo Cave, New Mexico

\begin{tabular}{lccl}
\hline Lab no. & $\begin{array}{c}{ }^{14} \mathrm{C} \text { age } \\
(\mathrm{BP})\end{array}$ & $\begin{array}{c}\delta^{13} \mathrm{C} \\
(\% 0)\end{array}$ & Material/pretreatment \\
\hline UCR-2603 & $12,970 \pm 170$ & -22.9 & Wood: ABA \\
UCR-3276B/CAMS-12366 & $12,370 \pm 80$ & -16.2 & Hair: water treated \\
UCR-3276/CAMS-12367 & $12,240 \pm 70$ & -17.1 & Hair: total amino acids* \\
\hline
\end{tabular}

*See text for discussion of species from which hair is derived.

To examine the biochemical characteristics of the hair samples and provide baseline data for future comparisons with less well-preserved samples, we have obtained amino acid composition (Fig. 3), carbon/nitrogen (C/N) ratios (Fig. 5) and $\delta^{13} \mathrm{C}$ values (Fig. 6). We also measured the associated bone samples (Fig. 4) to determine the degree to which the collagen pattern is maintained. Amino acid composition was obtained by ion-exchange liquid chromatography with post-column derivatization using o-phthaldialdehyde (OPA) and fluorescence detection. In this system, proline and hydroxyproline are not detected (Benson and Hare 1975). C/N ratios were obtained on a Carlo-Erba NA $1500 \mathrm{C} / \mathrm{N} / \mathrm{S}$ analyzer. 


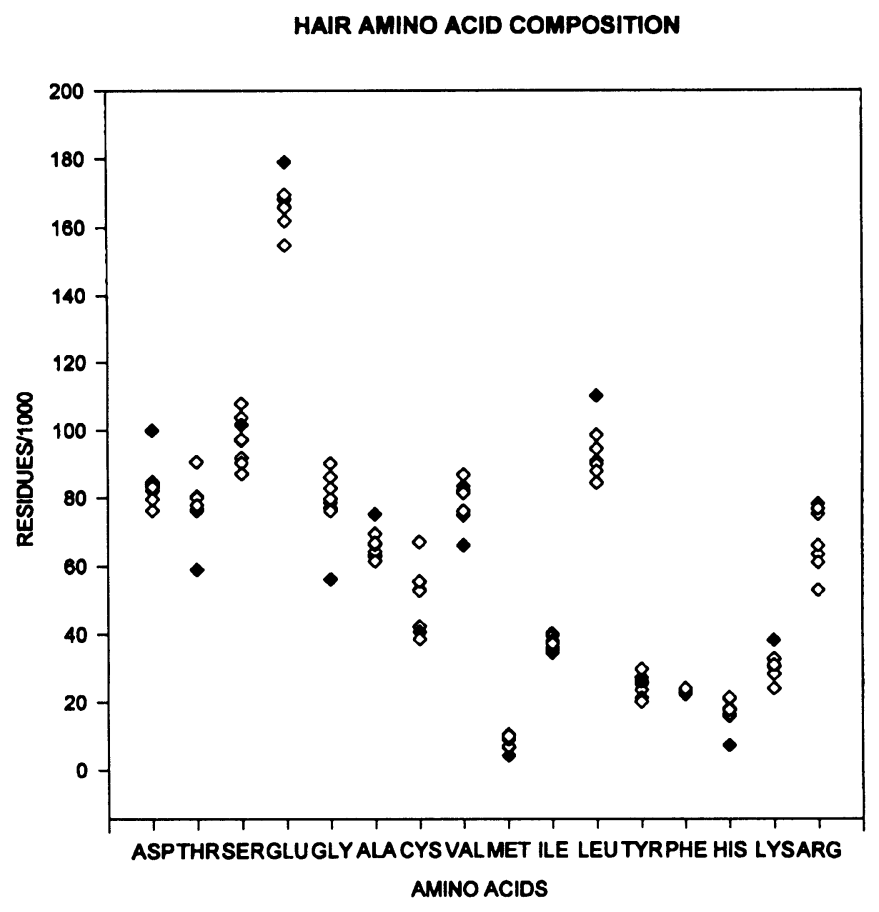

BONE AMINO ACID COMPOSITION

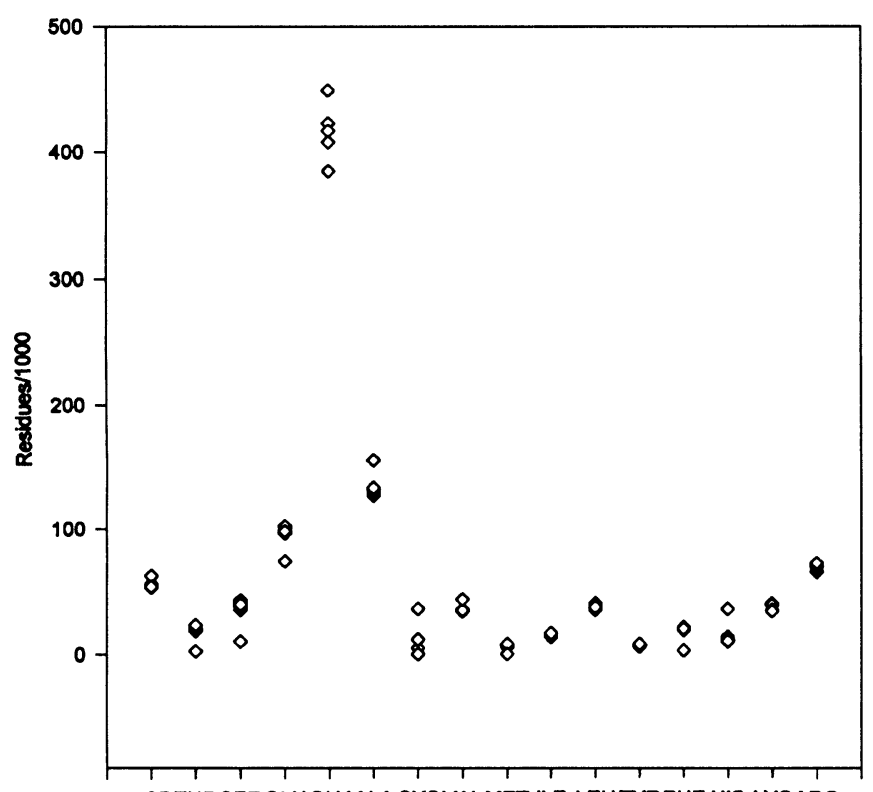

ASPTHRSERGLUGLYALACYSVALMET ILE LEUTYRPHE HIS LYSARG

Amino Acids
Fig 3. Amino acid composition of $\mathrm{Ne}$ vada hair samples. Mogoose and Fish Cave samples were not measured. Composition expressed in residues $/ 1000$; proline and hydroxyproline not detected. $\diamond=$ Nevada hair samples; $=$ average values based on compilation of previous measurements by other investigators (Yu et al. 1993).
Fig. 4. Amino acid composition of Nevada bone samples. Pyramid Lake Cave-729t and Blazing Star Cave samples not measured. Composition expressed in residues/ 1000. Proline and hydroxyproline not detected. 
As expected from previous amino acid measurements on hair (Yu et al. 1993; cf. Fig. 3), the Nevada hair samples showed larger amounts of cystine (Cys) than bone, reflecting the sulfur-rich characteristics of keratin. With the exception of Cys and arginine, most of the amino acid values are tightly clustered. The greater variability in Cys values may reflect variability in the degree of oxidation of cystine to cysteic acid. The $\mathrm{C} / \mathrm{N}$ ratios (Fig. 5) and the Gly/Glu and Gly/Asp ratios (Fig. 3) lie in a narrow range, indicating relatively well-preserved chemical structures. The amino acid composition (Fig. 4) and C/N ratios (Fig. 5) of all the bone samples are in the range characteristic of intact collagen (Hare and von Endt 1990).

There appear to be progressive shifts to less negative $\delta^{13} \mathrm{C}$ values exhibited in the sequence of bulk hair samples (cleaned by sonication in $\mathrm{H}_{2} \mathrm{O}$ ), the hair TAA fraction, and the bone TAA fraction of hair and bone from the same skeleton (Fig. 6). For example, the $\delta^{13} \mathrm{C}$ value of the $\mathrm{H}_{2} \mathrm{O}$-cleaned hair from Chimney Cave is $-17.0 \%$, the hair TAA fraction, $-16 . \%$, and the bone TAA fraction $-14.2 \%$. In addition, $\delta^{13} \mathrm{C}$ values in both hair and bone appear to shift to less negative values in middle Holocene age samples. More negative $\delta^{13} \mathrm{C}$ values are exhibited in the early Holocene Spirit Cave materials. Several explanations for these observed shifts include: 1 ) differences in hair and bone metabolic turnover rates; 2) differential fractionation effects in our ion-exchange chromatography procedures; and 3) regional climatic effects. In one group of samples studied recently, hair appeared more accurately to reflect ante-mortem $\delta^{13} \mathrm{C}$ values than bone (Aufderheide et al. 1994).

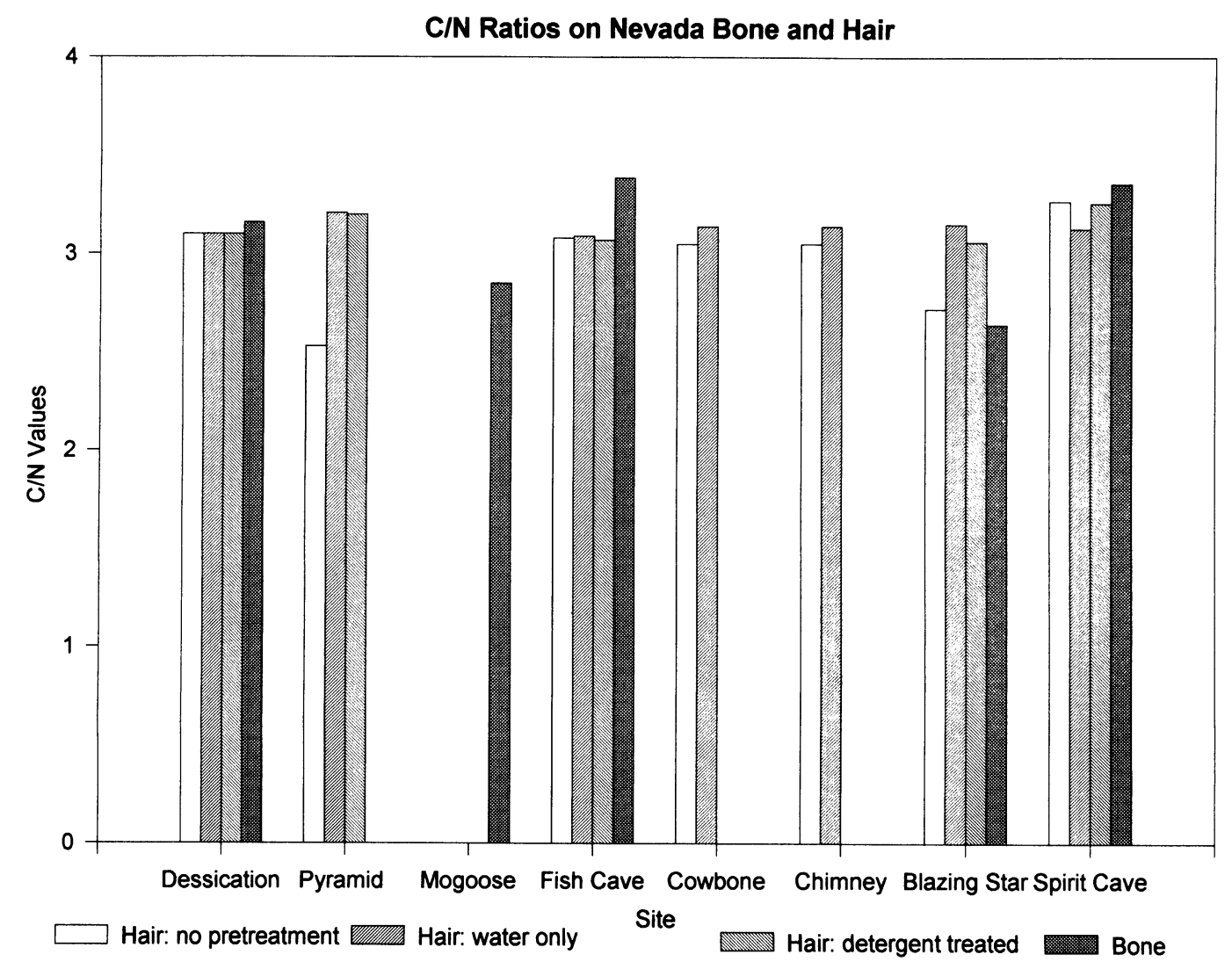

Fig. 5. C/N ratios on Nevada hair and bone samples 


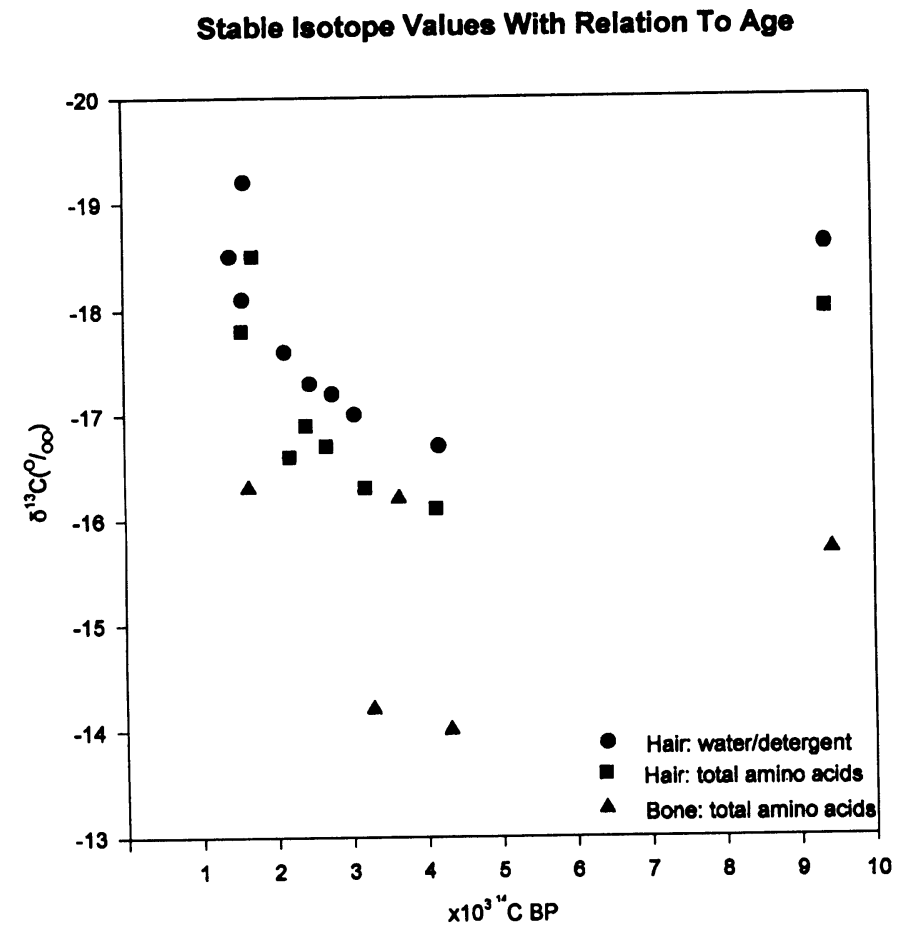

Fig. $6 . \delta^{13} \mathrm{C}$ values in relation to age of Nevada hair and bone series

\section{ConClusion}

We have obtained a series of ${ }^{14} \mathrm{C}$ age determinations on hair samples from several cave and rock shelter sites in Nevada and New Mexico. We used different pretreatment on these samples, whose ages may be compared with ${ }^{14} \mathrm{C}$ values on TAA fractions of bone and other associated organic material. The deviation in ${ }^{14} \mathrm{C}$ ages between hair with no pretreatment and the TAA fraction of the same hair sample does not exceed ca. $250 \mathrm{yr}$. Our samples appear to have been affected only by external surface contamination that could be removed by water pretreatment alone; it was not necessary to use detergent or solvent solutions. When we take into account non-contamination-based offset in ${ }^{14} \mathrm{C}$ ages exhibited in the TAA fractions, there is very good to excellent concordance in ${ }^{14} \mathrm{C}$ ages of hair and bone TAA fractions. We conclude that hair, if properly pretreated, can provide accurate ${ }^{14} \mathrm{C}$ age determinations. Our bone TAA ${ }^{14} \mathrm{C}$ values were obtained on skeletal materials that exhibit collagen-like amino acid and $C / N$ patterns. Future research will seek to examine hair associated with bone that has lost its collagen-like amino-acid profiles and $\mathrm{C} / \mathrm{N}$ ratios.

\section{ACKNOWLEDGMENTS}

The UCR Radiocarbon Laboratory is supported by the Gabrielle O. Vierra Memorial Fund, the Intermural Research Fund and the College of Humanities and Social Sciences, University of California, Riverside. We appreciate the very helpful collaboration of John R. Southon and the support of Jay Davis of the Center for Accelerator Mass Spectrometry, University of California Lawrence Livermore National Laboratory, Livermore, California in obtaining AMS ${ }^{14} \mathrm{C}$ measurements, and David Winter of the Institute of Geophysics and Planetary Physics, University of California, Los Angeles for $\delta^{13} \mathrm{C}$ measurements. We also thank Prof. S. Claesson of the Laboratory for Isotope 
Geology of the Swedish Museum of Natural History, Stockholm, Sweden concerning the details of the analysis of the Dome Creek Mammoth, Dr. R. E. M. Hedges of the Oxford AMS Laboratory for information on pretreatment for hair used at his laboratory, Larry Toolin of the NSF-Arizona AMS Facility for information on pretreatment for hair used in the Arizona AMS laboratory, and C. J. Hopkins, Forensic Sciences Division, FBI, Washington, DC for the identification of the hair sample from Pendejo Cave. The collaboration of Amy Dansie and Donald Tuohy of the Nevada State Museum in obtaining hair and bone samples and photographs of the burials and Donald Chrisman, M.D., Geoffrey Cunnar, and Dr. R. S. MacNeish in obtaining the Pendejo Cave hair sample is very much appreciated. Photographs of the Nevada samples were obtained by Scott Klette of the Nevada State Museum, Carson City, Nevada. We also acknowledge the helpful assistance of Manuel Mundo, Department of Nematology, UCR, in the use of the SEM instrument and Michaele Kashgarian, AMS Laboratory, LLNL, in the measurement of our samples at LLNL. The comments of P. J. Wilke on an earlier draft of this paper is also acknowledged. This is contribution 94/03 of the Institute of Geophysics and Planetary Physics, University of California, Riverside.

\section{REFERENCES}

Aufderheide, A. C., Kelley, M. A., Rivera, M., Gray, L., Tieszen, L. L., Iversen, E., Krouse, H. R., and Carevic, A. 1994 Contributions of chemical dietary reconstruction to the assessment of adaptation by ancient highland immigrants (Alto Ramirez) to coastal conditions at Pisagua, North Chile. Journal of Archaeological Science 21: 515-524.

Barrnett, R. J. and Sognnaes, R. F. 1962 Histochemical distribution of protein-bound sulfhydryl and disulfide groups in vertebrate keratins. In Butcher, E. O. and Sognnaes, R. F., eds., Fundamentals of Keratinization. Washington, DC, American Association for the Advancement of Science: $27-43$.

Benson, J. R. and Hare, P. E. 1975 o-Phthalaldehyde: Fluorogenic detection of primary amines in the picomole range. Comparison with fluorescamine and ninydrin. Proceedings of the National Academy of Sciences 72: 619-622.

Butcher, E. O. and Sognnaes, R. F., eds. 1962 Fundamentals of Keratinization. Washington, DC, American Association for the Advancement of Science: $189 \mathrm{p}$.

Fraser, R. B. D., MacRae, T. P. and Rogers, G. E. 1972 Keratins: Their Composition, Structure and Biosynthesis. Springfield, Illinois, Charles C. Thomas: 304 p.

Gillespie, J. M. 1970 Mammoth hair: Stability of alpha-keratin structure. Science 170: 1100-1102.

Goldman, R. and Steinert, P. M., eds. 1990 Cellular and Molecular Biology of Intermediate Filaments. New York: Plenum Publishing Corporation: 479 p.

Hare, P. E. and von Endt, D. 1990 Variable preservation of organic matter in fossil bone. 1989 Yearbook of the Carnegie Institution of Washington. Washington, DC, Carnegie Institution of Washington.

Haynes, C. V., Jr. 1992 Contribution of radiocarbon dating to the geochronology of the peopling of the New World. In Taylor, R. E., Long, A., and Kra, R. S. eds., Radiocarbon After Four Decades: An Interdisciplinary Perspective. New York, Springer-Verlag: 355-374.
Hedges, R. E. M., Housley, R. A., Law, L. A. and Perry, C. 1987 Radiocarbon dates from the Oxford AMS System: Archaeometry datelist 5. Archaeometry 29: 125-155.

1988 Radiocarbon dates from the Oxford AMS System: Archaeometry datelist 7. Archaeometry 30: 155164.

Hedges, R. E. M., Housley, R. A., Ramsey, C. B. and van Klinken, G. R. 1993 Radiocarbon dates from the Oxford AMS system: Archaeometry datelist 16. Archaeometry 35:147-167.

Jope, E. M. 1980 Ancient bone and plant proteins: The molecular state of preservation. In Hare, P. E., Hoering, T. C. and King, K., Jr., eds., Biogeochemistry of Amino Acids. New York, John Wiley \& Sons: 23-34.

Kirner, D., Taylor, R. E. and Southon, J. R. 1995 Reduction of backgrounds in microsamples for $\mathrm{AMS}{ }^{14} \mathrm{C}$ dating. Radiocarbon, this issue.

Libby, W. F. 1952 Radiocarbon Dating. Chicago, University of Chicago Press: $124 \mathrm{p}$.

1955 Radiocarbon Dating. 2nd edition. Chicago, University of Chicago Press: $175 \mathrm{p}$.

Marshall R. C. 1983 Characterization of the proteins of human hair and nail by electrophoresis. Journal of Investigative Dermatology 80: 519-524.

MacNeish, R. S., Cunnar G., Jessop, G. and Wilner, P. 1993 A Summary of the Paleo-Indian Discoveries in Pendejo Cave near Orogrande, New Mexico. Andover, Massachsuetts, Andover Foundation for Archaeological Research.

Southon, J. R., Vogel, J. S. Trumbore, S. E., Davis, J. C., Roberts, M. L., Caffee, M. W., Finkel, R. C., Proctor, I. D., Heikkinen, D. W., Berno, A. J. and Hornady, R. S. 1992 Progress in AMS measurements at the LLNL spectrometer. In Long, A. and Kra., R. S., Proceedings of the 14 th International ${ }^{14} \mathrm{C}$ Conference. Radiocarbon 34(3): 473-477.

Southon, J. R., Caffee, M. W., Davis, J. C., Moore, T. L., 
Proctor, I. D., Schumacher, B. and Vogel, J. S. 1990 The new LLNL AMS spectrometer. Nuclear Instruments and Methods in Physics Research B52: 301305.

Sperling, L. C. 1991 Hair anatomy for the clinician. Journal of the American Academy of Dermatology 25:117.

Stafford, T. W., Jr. 1994 Accelerator C-14 dating of human fossil skeletons: Assessing accuracy and results on New World specimens. In Bonnichsen, R. and Steele, D. G., eds., Method and Theory for Investigating the Peopling of the Americas. Corvallis, Oregon, Oregon State University Center for the Study of the First Americans: 45-55.

Stafford, T. W., Jr., Hare, P. E., Currie, L., Jull, A. J. T. and Donahue, D. 1990 Accuracy of North American human skeleton ages. Quaternary Research 34: 111120.

1991 Accelerator radiocarbon dating at the molecular level. Journal of Archaeological Science 18: 3572.

Taylor, R. E. 1987 AMS ${ }^{14} \mathrm{C}$ dating of critical bone samples: Proposed protocol and criteria for evaluation.
Nuclear Instruments and Methods in Physics Research B29: 159-163.

1992 Radiocarbon dating of bone: To collagen and beyond. In Taylor, R. E., Long A., and Kra, R. S., eds., Radiocarbon After Four Decades: An Interdisciplinary Perspective. New York: Springer-Verlag: 375402.

1994 Radiocarbon dating of bone using accelerator mass spectrometry: Current discussion and future directions. In Bonnichsen, R. and Steele, D. G., eds., Method and Theory for Investigating the Peopling of the Americas. Corvallis, Oregon, Oregon State University Center for the Study of the First Americans: $27-44$.

Yu, J., Yu, D., Checkla, D. M., Freedberg, I. M. and Bertolino, A. P. 1993 Human hair keratins. Journal of Investigative Dermatology 101:56-59.

Wheeler, S. M. 1943 (ms.) Cave burials near Fallon, Nevada. Paper on file at the Nevada State Museum, Carson City.

Wheeler, S. M. and Wheeler, G. N. 1969 Cave Burials near Fallon, Churchill County, Nevada. Nevada State Museum Anthropological Papers 14: 70-78. 